\title{
Artistic languages and children's natural development in Waldorf pedagogy: a case study based on happiness
}

\author{
Elena Guichot-Muñoz, University os Seville, Seville, Spain, eguichot1@us.es, https://orcid.org/0000-0001- \\ 6017-8837
}

Giulia De Sarlo, University os Seville, Seville, Spain, gdesarlo@us.es, https://orcid.org/0000-0002-7204$258 X$

Susana García-Barragán, CEIP Nuestra Señora de la Soledad, Cantillana, Seville, Spain, susanagarciabarragan@gmail.com

Olga Moreno-Fernández, University of Seville, Seville, Spain, omoreno@us.es, https://orcid.org/00000003-4349-8657

\begin{abstract}
It is a fact that the traditional school model is not in harmony with the new current of Positive Psychology applied to Education, since this states that emotional education, art and respect for children's natural development are pedagogical imperatives for their emotional well-being. According to Steiner's philosophy, Waldorf pedagogy can be considered as a model in this sense: the main objective of this article is to verify this hypothesis and identify the factors that provide this state of school welfare. Methodologically, a case study is proposed which examines the keys to the motivational success of a group of Waldorf students and identifies the factors that promote happiness in that context through observation and compliance with the Subjective Happiness Scale. The results, with an average of 4' 96 of SHS Subjective Happiness, confirm the hypothesis, and the research shows that the most representative motivational factors are the artistic-languages-based curriculum and the respect for children's natural development.
\end{abstract}

Keywords: Waldorf pedagogy, Natural development, Artistic languages, Happiness, Education

Received: $13.11 .2020 \quad$ Accepted: 10.12.2020 $\quad$ Published: 06.01.2021

\section{INTRODUCTION}

More and more groups of parents and teachers are demanding a new model of education, where the dissemination of values (Jiménez, 2006), the consideration of the particularity of each child and the respect for their childhood is a pillar (Rodríguez, 2013). That is why the Waldorf method has often been indicated as a model of education where happiness, contact with nature and individual development are raised as indisputable flags (Gaya, 2017).

Waldorf schools have been multiplying exponentially: while in 1956 there were a total of 62 Waldorf schools around the world, in 1975 they had doubled, and by 1992 the number of schools had increased fivefold to 567 (Quiroga \& Girard, 2015). Today there are approximately 1843 kindergartens in more than 70 countries and 1080 Waldorf schools in 64 countries (Igelmo-Zaldívar \& Quiroga, 2018). However, this method has been accused of being eccentric and charged with high spiritual content (Gaya, 2017): this paper will also face this fact, presenting a neuroscientific and updated approach to the method itself. Consequently, we work to identify and characterise Waldorf successful aspects which are also supported by the new discoveries of neuroscience. Neuroscience has proved the existence of a motivational system (Bustos, 2008) whose main function is the modulation and activation of the sensory and muscular structures. This system is related to a greater possibility of achieving an effective and significant learning process.

This work has, therefore, a double objective. Its first aim is to test the hypothesis of the high perception of motivation and happiness that can easily be recognised in Waldorf students, identifying these two items as keys to success for academic performance and student welfare (Izquierdo, 2016). The second objective is to identify the specific aspects of Waldorf pedagogy that are supported by neuroscience and recognised as elements that create an optimal context for learning.

\section{Outline of Waldorf Education}

In the first place, it seems necessary to start with a brief description of Waldorf pedagogy. It is inherent in the figure of its creator, Rudolf Steiner (1861-1925), a man with an outstanding academic background in many different fields of study. His main interest was the investigation of the scientific knowledge of the 
suprasensible; however, his spiritual discourse led the German scientific elite to classify him within theosophy, a field in which he also found no support and was forced to abandon. That is why in 1913 he inaugurated his own vision of the conception of the human being, which he would later call 'Anthroposophy' (Carlgren, 2004). Nevertheless, Waldorf education as we know it today started in 1919 in Germany, following the request of a German businessman, owner of the Waldorf-Astoria cigarette factory, who wanted to offer free education to the children of his workers. Waldorf first school and its theoretical foundation were internationalised practically from its origins. Today, with its almost 100 years of history (Quiroga \& Girard, 2015), there are almost 2000 kindergartens, 1056 schools and 646 therapeutic pedagogical centres around the world. This success is due, in part, to the revolutionary pedagogical foundations it proposes.

One of the significant features of Waldorf education is the predominant role given to artistic practices (Moreno, 2010, p. 205). As Carlgren (2004) points out: "all of this teaching will be given through the 'living word', avoiding textbooks, in the first courses decidedly, but also to a great extent in the higher courses" (p. 113-114), with the exception of texts with artistic or scientific value. In addition to the absence of textbooks, there were no examinations (Manzano \& Álvarez Monteserín, 2012). According to Moreno (2010), this prevents education from becoming a continuous competitive act and gives clues to the importance and care with which the nature of the child and his/her evolution are treated.

In this sense, in order to be a Waldorf teacher, several specific qualification courses and training must be fulfilled. It must be understood that within this pedagogy the position of the tutor teacher is of the utmost importance since he/she only will accompany a group throughout their whole school career (Carlgren, 2004). Malagón remarks that this is a perfect way to cultivate the human bond, a bond of trust which is fundamental for communication between students and teachers (2012).

To promote this human tie, an unmistakable hallmark of Waldorf schools lies in the aesthetics they all present. As Gayá (2017) describes: "Nature is the protagonist: courtyards in the woods, sand, ropes, outings to the countryside. (...) Nature is present in what they touch and learn: wooden dolls, cotton carpets, stones, slates, watercolours, wools" (p.1). Along with aesthetics, another element that shapes the Waldorf "atmosphere" is the strong family presence at school. Waldorf schools are organised by the socalled Active Educational Community, which Malagón (2017) defines as "teachers and families (that) enter into new learning processes, into processes of joint work to give coherence to the life of the children and pupils both in the family and in the school (p. 32).

\section{Waldorf education and children: what do we mean by happiness?}

Nowadays, when talking about happiness, philosophy of science places the concept of well-being in a prominent place. According to Mosterín (2008), happiness is the result of the juxtaposition of well-being and the achievement of our ultimate goals. Happiness would, therefore, have two components: a hedonistic one and another one of intimate satisfaction given by personal achievement. Translating all of this into education would imply seeking to achieve goals through a path that fosters student participation, enthusiasm, and motivation throughout the process.

In this sense, these concepts have been applied to the educational world in several cases through the last years, and at the present time we already speak of an emerging discipline: "Positive Education", that is, Positive Psychology applied to Education (Selligman et al., 2009) This current, supported by neuroscience, covers areas such as emotional education, optimism, creativity, sense of humour, motivation, mindfulness, strengths, resilience, gratitude, enthusiasm, self-esteem, assertiveness or compassion, among others (Gillham et al., 2013; Schueller \& Selligman, 2010).

The pedagogical model proposed by Steiner addresses all of these items, promoting an education where creativity and cultural development (Prager, 2004), respect for children's natural development and emotional well-being are pedagogical imperatives. Educating emotions requires alternative subjects that focus on children's nature and their changing temperament, which is by nature full of intense emotions (Bisquerra, 2012). With this idea in mind, peculiar subjects which are exclusively present in the Waldorf curriculum arise, such as Eurythmy; their main goal is to recognise the child as a free subject, capable of living in harmony with other people and with the world.

For this reason, our research questions are the following: Is the hypothesis of Waldorf students' intrinsic motivation and happiness true? If so, what specific elements present in this pedagogy and supported by neuroscience, are decisive in creating an optimal learning context?

\section{METHODS}

In order to carry out the proposed objectives. A mixed research has been developed, with a preponderance of qualitative research due to the nature of the aspects to be evaluated. Within the wide 
range of qualitative approach, the research is focused on a collective case study (Stake, 1994, 1998): specifically, the case of the Libera Scuola Waldorf di Palermo (from now on, LSWP). For this reason, the researcher carried out an ethnographic study during a three-month stay, from the perspective of authors such as Yin (2017), Sliwka, (2008) or Velasco (2003).

\section{Sample and context}

The selected sample was composed by the students of LSWP Primary School fourth and fifth classes. The choice of this sample is due to the fact that the fourth and fifth classes, aged between 9 and 11, are situated right in the middle of the eight academic levels of a Waldorf School. This implies the advantage of a more balanced perspective.

Table 1. Distribution by number, sex and age of the sample

\begin{tabular}{|l|l|l|l|l|}
\hline & Fourth grade & Fifth grade & Total & $\mathbf{f ~ ( \% )}$ \\
\hline Male & 7 & 1 & 8 & 36.0 \\
\hline Female & 6 & 8 & 14 & 64.0 \\
\hline Total & 13 & 9 & 22 & 100.0 \\
\hline
\end{tabular}

It is also necessary to make a brief description of the school in which the sample is included. It is a private centre located in the capital of Sicily (Italy), in a wealthy neighbourhood. Due to its location and prices, the student body is generally upper-middle-class, with the exception of more humble families who pay on a reduced basis through schoolwork. The school itself is organised in large and comfortable spaces; the garden and the huge central courtyard are the focus of school life.

\section{Instruments}

The research instruments have been of diverse nature, and it is a key aspect of the case study method (Soy, 1997). Nevertheless, observation is the main method that allows the subsequent articulation of the rest of the data-gathering process, with the teacher's diary as a key instrument (Strauss and Corbin, 2008). The observation was conducted for three months during school hours: this lapse of time included a three-month internship, with data collection during the last month. As Taylor, Bodgan \& Devault (2015) point out, "there are sometimes advantages in having a familiar role within a determined setting. Access is more easily obtained; the observer has always something to do; participants are not completely conscious of the researcher's presence and some data are more accessible" (p. 57). Immersion in the school's day-to-day life has made it possible to take an in-depth perspective and to select specific questions according to the school reality and the level of maturity of the selected sample. The following questionnaires have also been used:

- A first questionnaire that measured happiness through a Subjective Happiness Survey (SHS) (Lyubomirsky and Lepper, 1999). This scale is a global measure of subjective happiness, which evaluates a molar category of well-being as a global psychological phenomenon, considering the definition of happiness from the respondent's perspective. It consists of 4 items with Likert-type response. With this instrument, we hope to obtain a standardized measure of happiness levels.

- The second instrument is an ad hoc questionnaire that examines another fulcrum of our study: the search for the items that promote levels of happiness and motivation. All the readings on Waldorf pedagogy and the observations made at LSWP have been taken into account in its preparation. The questionnaire is divided into two questions: a) An open-ended question of a range of answers, to explore the opinions of the students, and b) An open-ended question of an estimation type, based on the classification of Casas, Repullo and Donado (2002). For this last question, a visual format has been chosen to achieve a more adequate estimation through emoticons according to the sensation produced by each variable 'Very happy', 'Somewhat happy' or 'Not very happy'.

\section{Data Analysis}

Working with qualitative variables implies a peculiar data processing since they are not easily measurable. Therefore, both statistical and content analysis are carried out with the purpose of "discovering concepts and relationships in the raw data and then organizing them into a theoretical explanatory scheme" (Strauss and Corbin, 2008, p. 81). Data analysis has been carried out differently depending on the nature of each question: 
a) The scale of evaluation of subjective happiness, being a universal test, presents its own evaluation. For this purpose, arithmetic mean, standard deviation and Cronbach's Alpha have been calculated, which allows for the calculation of reliability.

b) Open questions have the advantage of providing a great deal of information and a maximum of freedom to the respondent; however, the coding of the answers may involve certain difficulties and require a greater effort from the respondent to answer (Casas et al., 2002). In order to analyse these questions, the responses were interpreted and a total of 22 categories were created. For the last part of this questionnaire, by establishing three response options, the measures of centralisation are calculated, as well as those of dispersion.

\section{RESULTS}

\section{Analysis of the results of the SHS Subjective Happiness questionnaire}

The average score on the Subjective Happiness Scale was 4.96 (SD = 1.46). In estimating reliability using Cronbach's Alpha, a value of 0.71 was obtained, which is an acceptable value following George and Mallery (2003), and A Jisu, Delorme and Reid (2006):

Table 2. Overall measures of centralization, dispersion and reliability of the Subjective Happiness Scale

\begin{tabular}{|c|c|c|c|}
\hline Total & Measure & Standard deviation & Cronbach's alpha \\
\hline P1 & 5.70 & 1.06 & \multirow{5}{*}{0.71} \\
\hline $\mathrm{P} 2$ & 5.28 & 1.22 & \\
\hline P3 & 3.74 & 1.94 & \\
\hline $\mathrm{P} 4$ & 5.74 & 1.36 & \\
\hline Total & 4.96 & 1.46 & \\
\hline
\end{tabular}

According to these results, it can be stated that fourth and fifth-grade students consider themselves happy: a clear sign of optimism, a pillar of positive psychology. Optimism is a dispositional psychological characteristic that refers to positive expectations and future goals and that is deeply related to variables such as perseverance, achievement, physical health and well-being (Peterson and Bossio, 1991). Happiness and motivation are two sides of the same reality. Regarding the origin of this, it has been proven that people who experience many positive events and few negative ones have higher scores in subjective well-being than those who have to face many adversities if these are not balanced by a high number of positive experiences (Eronen et al., 1998). Therefore, it is possible to state that this feeling of happiness is due to a number of positive experiences, and our focus of interest is on those that occur in the school environment, in order to identify good practices in Waldorf pedagogy.

\section{Analysis of attributional factors to school motivation}

The values obtained in the Subjective Happiness Scale (SHS) are conclusive; however, these same values could be obtained in any other school, and not necessarily in a Waldorf context. Therefore, the research goes further: once the initial hypothesis is confirmed, the aim is to identify which variables generate this environment of well-being. The second question, of an open nature, has allowed us to delve into the perceptions of the students without conditioning their answers. Asking "What are the three things you like best about your school?" entailed the risk of getting as many different answers as the students surveyed, yet surprisingly many of the answers were almost identical and all of them can be aggregated into 22 model answers, which can be grouped into five categories: subjects, school context, teaching staff, methodology, leisure-time assessment. These categories group all the answers given according to their nature.

Table 3. Classification of the answers obtained to the second question of the questionnaire

\begin{tabular}{|l|l|}
\hline Categories & Items \\
\hline \multirow{4}{*}{ Subjects } & Unconventional subjects \\
\cline { 2 - 2 } & Eurythmy class \\
\cline { 2 - 2 } & English class \\
\cline { 2 - 2 } & Craft class \\
\cline { 2 - 2 } & Math class \\
\hline
\end{tabular}




\begin{tabular}{|l|l|}
\hline \multirow{4}{*}{ School context } & Music class \\
\cline { 2 - 2 } & Tutorial \\
\hline \multirow{4}{*}{ Teaching staff } & Familiar ambience \\
\cline { 2 - 2 } & Decoration \\
\cline { 2 - 2 } & Quality of food \\
\cline { 2 - 2 } & Freedom \\
\hline \multirow{5}{*}{ Methodology } & Teachers \\
\cline { 2 - 2 } & Volunteers \\
\cline { 2 - 2 } Leisure-time & Reduced homework's \\
\cline { 2 - 2 } assessment & Draw frequently \\
\cline { 2 - 2 } & Playful lessons \\
\cline { 2 - 2 } & Acting and reciting \\
\cline { 2 - 2 } & Unique teacher \\
\hline & Rest \\
\cline { 2 - 2 } & Garden \\
\cline { 2 - 2 } & Recreation \\
\hline
\end{tabular}

The distribution of responses in each of the determined categories corresponds to the following percentages (Figure 1):

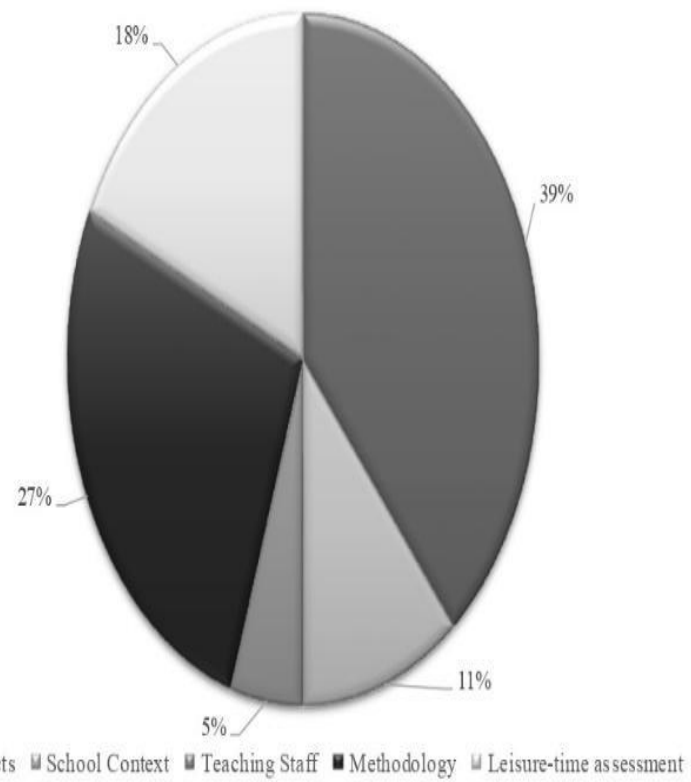

Figure 1. Distribution of responses by category

In the light of the results obtained we can see that most of the answers refer, firstly, to the subjects, secondly, to the methodology and thirdly to the assessment of leisure time. However, in order to go deeper into the items, the following figure can be reached (Figure 2): 


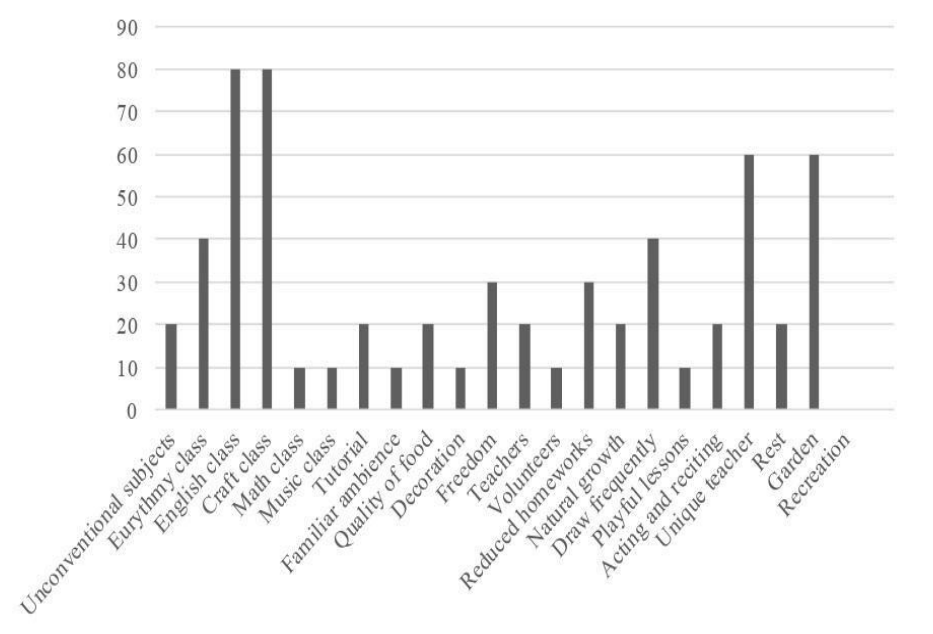

Figure 2. Detailed distribution of the second question

The distribution of the answers clearly indicates the subjects of English and handicrafts as a source of enjoyment, followed by the fact of having a single teacher for the whole primary school stage (central question of the methodological approach) and the possibility to access a large garden. Other elements that are often positively valued are drawing and recess, in the same way as the subject of Eurythmy.

First of all, in order to understand the extremely high reception of the English classes, it is important to refer to the ethnographic study. The teacher of this subject is a teacher who brings a playful atmosphere to all her lessons; she mainly works with word games, jokes, rhymes and songs. Working with the mother tongue and foreign languages in an integral way, in a creative and playful frame, is not only decisive but also a successful practice with the students (Cekaite \& Aronsson, 2004, Sullivan, 2000).

Secondly, handicrafts, the second most highly valued subject according to the results, is a core subject in Waldorf education. It usually develops different skills: knitting and crochet are normally the first steps and are maintained throughout the primary stage, complemented by work in wood, clay or even metal at a later age (Fugure 3).

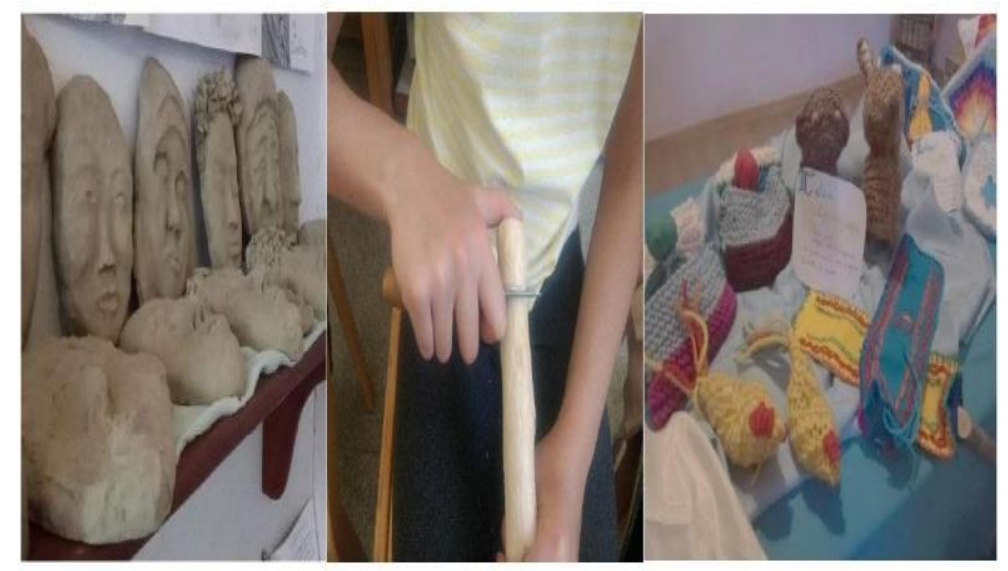

Figure 3. Handicrafts at LSWP

This practice is supported by studies that show that handicrafts can stimulate the neurological system and improve health and well-being, and help to alleviate anxiety, depression and even chronic pain (Gutman and Schindler, 2007; Kelly, Cudney, \& Weinert, 2012). Related to this, another recurring response to positive aspects of school was what is categorized as 'drawing frequently'. Within this pedagogy, drawing is a common learning medium for all subjects, even those traditionally less 'artistic' such as mathematics. After explanations or exercises on certain content, at Waldorf the students must make their own production of what happened, writing and drawing in their notebook what they have learned in that lesson, corroborating Housen's theory of visual thinking (Montanero, 2019) (Figure 4). 


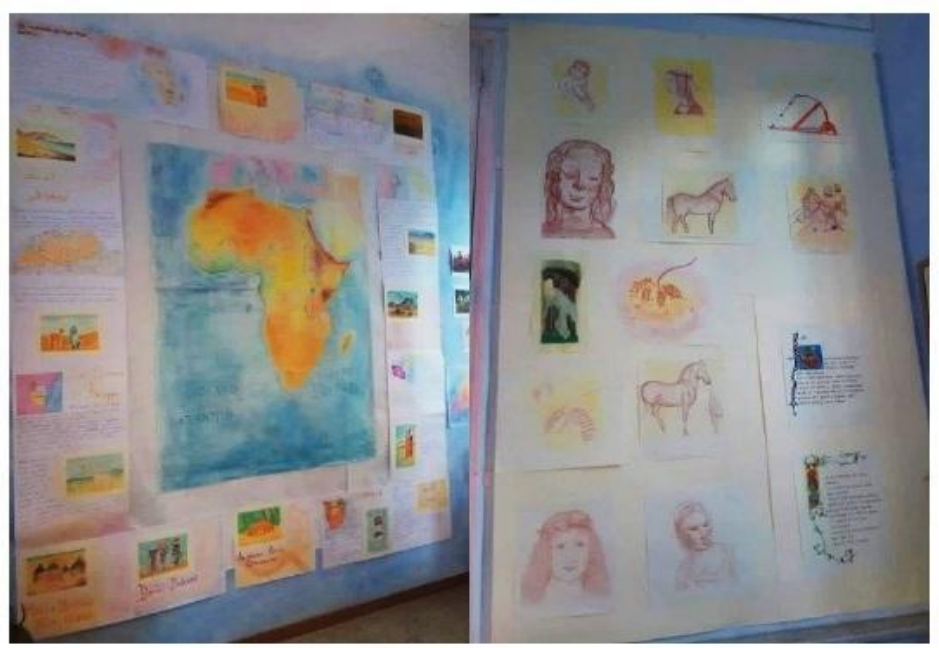

Figure 4. Exhibition of notebooks of different subjects and levels

Another success factor among students is the presence of a single tutor throughout the primary stage. Child development and school learning take place through a relationship of trust between the children and their teachers, in the environment around them and in their perception of the world. In the vital shaping of this relationship, Waldorf teachers take on a special responsibility (International Waldorf Education Forum/Steiner, 2016). According to pedagogical neuroscience, teachers develop a network of actions which, together with the students, produce the transformation of knowledge, values and abilities. These processes enable integrated mental and cultural experience (Francis, 2005). Perpetuating a teacher for an entire school cycle makes it possible to build levels of mutual trust and knowledge that are difficult to achieve in a single school year. In addition, Waldorf teachers' preparation is specific for each school year, with a permanent training academy (Quiroga \& Igelmo-Zaldívar, 2018).

As for the garden space, which is the most highly valued formal aspect, contact with nature stands as one of the pillars of Waldorf education (Gayá, 2017). Studies in environmental psychology suggest considering contact with nature in the design of programmes for the promotion of personal well-being (Marrero \& Carballeira, 2014). It has been shown that the potential of nature in leisure and human development would provide some advantages over artificial and human-dominated environments (Ried, 2015). More and more scientific studies are highlighting the importance of contact with nature for mental well-being, as Corraliza \& Collado (2011) point out. Some of these studies corroborate that simply visualizing scenes from nature or participating in activities within natural environments reduces mental fatigue (Taylor \& Kuo, 2006; Wells, 2000).

\section{Analysis of the subjects and methodology at LSWP}

Analyzing the "subject" category in depth, which is a total of 39 percent of the total responses, $6.1 \%$ of the positive aspects of the school are identified with the Eurythmy class, following English and crafts. Eurythmy is one of the most unique characteristics of Waldorf education: it is a compulsory subject at school and a common practice among those who are close to Steinerian doctrines. Also called "visible word" or "visible song", this discipline includes diverse practices such as learning the alphabet: "Eurythmists liberate this resonance which they transform into movement, helping themselves with their whole body and showing it with gestures. Each sound has its own movement" (Formación Eurritmia Madrid, 2018). The most evident work of Eurythmy is dance, but behind it, there are transversal contents such as phonetics, mathematics (working with geometric forms, numerology, etc.), meditative content and other more introspective aspects. The typical Eurythmy attire consists of a silk tunic and cotton eurythmy shoes with rubber soles. In higher courses, work with elements such as silk veils or bars is also included.

The work is carried out with harmonic music, for example in the case of LSWP the teacher guides the Eurythmy session with a piano. Although Eurythmy is inseparable from its esoteric features, its musical language cannot be ignored - dance and body movement, as well as its dependence on music and its effects on the brain:

Children enter into a musical culture where their innate communicative musicality can be encouraged and strengthened through sensitive, respectful, playful, culturally informed teaching in companionship. The central importance of our abilities for music as part of what sustains our well-being 
is supported by evidence that communicative musicality strengthens emotions of social resilience to aid recovery from mental stress and illness (Malloch \& Trevarthen, 2018, p. 1).

In their study, these authors focus on the hemispheric differences derived from music and dance and their relationship with Jaak Panksepp's affective neuroscience. They conclude that the psychobiological purpose of our innate musicality grows from the integrated rhythms of energy in the brain. This is generated when there is affective guidance, which seeks and generates the vitality of the movement.

On the other hand, it is interesting to examine the "methodology" category in detail, since all those responses that referred to pedagogical or performance characteristics of the school are analyzed there. As mentioned above, the majority of answers within this category refers to the fact of having a single teacher. Next, we find 'frequent drawing' and 'reduced homework'. This last element, with $4.5 \%$ of the total responses, is currently one of the most controversial issues in education. Studies regarding the improvement of academic performance based on the completion of homework are inconclusive in primary education (Valle et al., 2015). Positions also emerge that see the benefit of these reinforcement activities as exercises in learning to manage self-efficacy (Zimmerman \& Kitsantas, 2005), and studies that do show a positive and significant association between homework and achievement at both class and student levels (Cooper et al., 2006, Hattie and Clinton, 2001). In addition, there is an approach that considers homework as a possible way of linking what infants learn at school and within their own family (González, Lacasa \& Albuquerque, 2014). Therefore, the total rejection of homework is not totally justified. However, this research also admits that potentially confusing variables, such as the type of homework, the type of school, or the cognitive abilities of the student, are not controlled (Trautwein, 2007). In any case, the amount of homework can be a focus of discussion, as it goes against the natural development of the child. Respecting the leisure time of the youngest seems to be the most balanced position, and in this aspect, the educational community is clear: playing is a right and a necessity in childhood (Spanish Society of Pedagogy, 2013). In this sense, there are several studies that measure the stress of children and parents when facing excessive homework, or homework that discourages learning (Verma, Sharma and Larson, 2002, Goetz et al., 2012, Dettmers et al., 2011).

\section{Analysis of the artistic languages at LSWP}

The third item of the questionnaire collects the aspects noticed during the observation period as possibly responsible for the motivation and happiness perceived at LSWP. This question seeks to corroborate or refute these hypotheses based on the scientific evidence that led to their establishment as possible causes. The results obtained are enlightening: $75 \%$ of the answers confirm the hypothesis, and only $5 \%$ of the answers contradict it. This approach is encouraging; however, it is interesting to delve deeper into those items that have obtained a greater support. Before analysing the distribution of the percentages of each question, the following table is provided with the issues raised in the third question (Table 4):

Table 4. Items in question 3 of the questionnaire

\begin{tabular}{|l|l|}
\hline $\mathbf{N o}$ & Item \\
\hline 1 & Have a nice garden to play in. \\
\hline 2 & To be able to work with so many colours, pencils and waxes. \\
\hline 3 & See the drawings hanging on the walls \\
\hline 4 & Coloured walls with gradients \\
\hline 5 & Having a big table to work at \\
\hline 6 & Start every morning with a song \\
\hline 7 & To be able to receive classes in the courtyard \\
\hline 8 & The music classes \\
\hline 9 & Working with watercolours and paintings \\
\hline 10 & Eurythmy classes \\
\hline
\end{tabular}




\begin{tabular}{|l|l|}
\hline 11 & Poetry and drama \\
\hline 12 & Greet the teacher every day, before and after class \\
\hline 13.1 & Work the clay (class IV) \\
\hline 13.2 & Woodworking (V class) \\
\hline 14 & Craft classes \\
\hline 15 & Always have the same teacher \\
\hline 16 & Always have the same classmates \\
\hline
\end{tabular}

The distribution is very high in some items such as 1,2, 4 and 5 , which collect over $90 \%$ of positive answers. The first question refers to the presence of the garden in the school, a fact that was already highlighted in the second question, so this aspect will not be repeated. The second question is about the possibility of working with multiple colours, pencils and waxes. Since the methodology of drawing is part of the teaching-learning process, the students enrolled at Waldorf receive all the materials at the beginning of their first year of compulsory education. All the centres that are close to the Steinerian pedagogy bet on toxic-free materials, and there are specialised brands, such as 'Stockmar', that usually provide Waldorf schools and have a clear ecological and educational vision (Henward, 2018). Likewise, the concept of colour in Waldorf education is strongly influenced by the Goethean trend (Oberski, 2007). Johann Goethe studied colour from a psychological perspective, paying special attention to the effect of colour on perception and human behaviour. These studies concluded that colours are part of our vision: therefore, they are a sensory perception first of all (González \& Suerio, 2017). For this reason, approaches that rely on colour as an architectural therapeutic measure are of special interest to this research, as they recognise certain colours as conducive to states of well-being. These studies support one of the formal characteristics of Waldorf schools: the use of certain chromatic ranges on the walls, which obtains $95 \%$ of confirmatory responses as a source of happiness in the fourth item. In research on hospital environments such as that of Carmona \& Valero (2015), it has been proven that the appropriate use of colour in the environment is a key indicator of the positive stimulation and suitability of space for children and young people. In fact, Boyatzis \& Varghese (1994) carried out a study on children emotions as associated with different colours, and it resulted to be in line with the theories that Steiner used to create the Lazure technique. This technique consists of a mural painting that is exhibited in Waldorf schools for aesthetic reasons and for reasons linked to the infant's balance.

It is also interesting for our study that painting is included as an academic subject from the first year of Waldorf compulsory education. Why is this decisive? To quote Hargreaves (2002): "the arts provide unique opportunities for the development of personal qualities such as natural creative expression, social and moral values, and self-esteem" (p. 11). Neurological studies suggest that there is tremendous potential for preservation of brain functions created or developed by the visual arts. As Fornazzari (2008) points out, the reasons for that are not clear, but several theories are being considered, among which is the possibility that through the arts more elaborate neural pathways or better neural connections are developed in the brain areas related to visuospatial functions. Another theory considers the possibility that these specific neural pathways may be more resistant to the effects of brain pathology (Zaidel, 2015).

It is also worthwhile to go deeper into question 11 - about acting and reciting - since these two aspects are central to Steinerian pedagogy, and receive confirmative answers of happiness (between 70 and 89\%). Within the arts, Waldorf schools place special emphasis on theatrical work (called "reciting and acting"). Generally, an annual or quarterly performance is prepared: it usually deals with the central theme of each school stage, such as Nordic or classical mythology. For example, following Carlgren (2004), in the first course, Waldorf students work with stories, in the second with fables and legends and in the third with the Old Testament. Theatre or dance develop social-emotional skills such as empathy and are beneficial for semantic memory. In addition, another tangible socio-emotional aspect is the group cohesion that it generates, as well as the acquisition of responsibilities: students must elaborate the set and even their own clothes. In the field of neuroscience, discoveries by Rizzolatti and his team during the 1990s about mirror neurons open up new avenues for theatrical glotto didactics and confirm the importance of theatre in cognitive-emotional, empathic-communicative and imaginative processes for the educational curriculum (Baldwin, 2014). 


\section{DISCUSSION AND CONCLUSIONS}

According to these results, the two main objectives proposed at the beginning of this research work are confirmed. Firstly, through the subjective happiness questionnaire (SHS), the state of well-being of LSWP students has been qualitatively and quantitatively verified with an average of 4.96 . Secondly, through the period of observation carried out at LSWP, and the subsequent construction of a personalized questionnaire, it has been possible to delve into the items that directly influence the perception of happiness and motivation that students have. Synthesizing the results, the subjects related to artistic languages can be highlighted: they share a liberal treatment and use of playful methodologies by the teaching staff. Both handicrafts and Eurythmy are subjects based on artistic work, and as such, they activate processes of symbolization, expression and creativity in an integral way (Acaso, 2000). This promotes students' intellectual, emotional, creative and social advancement, even in situations of trauma (Hasio, 2011; Reynolds et al., 2012): in fact, recent studies propose the theory that Homo Sapiens used art not only as an aesthetic element but also to enhance unity, inclusion and cooperative behaviour: "HS [Homo Sapiens] could have exploited symbolically through art-rooted biological neural pathways for social purpose, namely, those controlling interpersonal motoric coordination and sound codependence" (Zaidel, 2018, p. 25). Authors such as Oberski (2007) and Montanero (2019) put Waldorf as a pioneer school in the discovery that intelligence and social thought do not emerge from direct instruction but from educating spiritual freedom from "imagination and artistic creativity: in painting, dance and music, poetry" (Montanero, 2019, p. 17).

Moreover, another pillar lies in the Waldorf pedagogical motto of respect for the children's natural development: that is, an education based on freedom within a non-competitive environment, without a high burden of homework, and with a sole tutor. Igelmo-Zaldívar and Quiroga define Waldorf as a 'light' pedagogy where "forgetting and remembering are assumed to be a natural part of the learning process" (2018, p. 86). From the neuroscience point of view, instruction, learning and motivation are essential in the development of children's brains. Positive life experiences, thoughts, emotions and behaviour can modulate expression and neurogenesis in such a way that they can actually change the physical structure of the brain (Kandel, 2000). Therefore, providing a quality education that is appropriate to the development of each school stage should be the driving force behind all pedagogical proposals.

One of the great challenges of this study was to support these items which were observationally, and then statistically, proven from a neuroscientific point of view. However, confirmatory studies would be needed to deepen the foundations laid here. The private status of this type of school is also to be taken into account since it should motivate a deeper socio-economic analysis of the relations within the country's educational community (Resende et al., 2011). Even so, the objective achieved consists of carrying out an outline of what are considered good practices in Waldorf education, opening up a discussion which will allow these successful actions to be extracted with a view to their implementation in other centres. It also contributes to understanding that an education based on positive emotions and meaning results in a situation in which students are stronger and more motivated (Kwok \& Fang, 2020): an education which is more in line with the expectations of child development in the 21st century (Smidt, 2013).

\section{REFERENCES}

Acaso, M. (2000). Simbolización, expresión y creatividad: tres propuestas sobre la necesidad de desarrollar la expresión plástica infantil [Symbolization, expression and creativity: three proposals on the need to develop children's plastic expression]. Arte, Individuo y Sociedad, 12, 4157.

Baldwin, P. (2012). With drama in mind. Real learning in imagined worlds. London: Bloomsbury Publishing.

Bisquerra, A. R. (2011). Educación emocional: propuesta para educadores y familias [Emotional education: a proposal for educators and families]. Paris: Desclée de Brouwer.

Boyatzis, C. J., \& Varghese, R. (1994). Children's emotional associations with colors. The Journal of genetic psychology, 155(1), 77-85.

Bustos M. (2008). Núcleo accumbens y el sistema motivacional a cargo del apego. Revista chilena de neuro-psiquiatría, 46(3), 207-215. https://dx.doi.org/10.4067/S0717-92272008000300006

Carlgren, F. (2004). Pedagogía Waldorf: Una educación hacia la libertad [Waldorf Pedagogy: An Education to Freedom]. Madrid: Editorial Rudolf Steiner.

Carmona, V., \& Valero, E. (2015). Arquitectura para la infancia en el entorno hospitalario [Architecture for children in the hospital environment]. Arquitectonics: Mind, Land \& Society, 27, 235-243. 
Casas, J., Repullo, J. R., \& Donado, J. (2002). La encuesta como técnica de investigación. Elaboración de cuestionarios y tratamiento estadístico de los datos [Surveys as a research technique. Composition of questionnaires and statistical processing of data]. Atención Primaria, 31(8), 527-38.

Cekaite, A., \& Aronsson, K. (2004). Repetition and Joking in Children's Second Language Conversations: Playful Recyclings in an Immersion Classroom. Discourse Studies, 6(3), 373-392. https://doi.org/10.1177/1461445604044295

Cooper, H., Robinson, J.C., \& Patall, E. A. (2006). Does homework improve academic achievement? A synthesis of research, 1987-2003. Review of Educational Research, 76, 1-62.

Corraliza, J. A., \& Collado, S. (2011). La naturaleza cercana como moderadora del estrés infantil [The close nature as a moderator of children's stress]. Psicothema, 23(2), 221-226.

Dettmers, S., Trautwein, U., Lüdtke, O., Goetz, T., Frenzel, A. C., \& Pekrun, R. (2011). Students' emotions during homework in mathematics: Testing a theoretical model of antecedents and achievement outcomes. Contemporary Educational Psychology, 36(1), 25-35.

Eronen, S., Nurmi, J. E., \& Salmela-Aro, K. (1998). Optimistic, defensive-pessimistic, impulsive and selfhandicapping strategies in university environments. Learning and Instruction, 8(2), 159-177.

Fornazzari, L. (2008). El papel del arte como protector de las funciones cerebrales. La música, la pintura y la escritura facilitan la capacidad de reserva cerebral [The paper of the art like protector of the cerebral functions. The music, the painting and the writing facilitate the capacity of cerebral reserve]. Revista mexicana de neurociencia, 9(2), 154-158.

Francis, S. (2005). El aporte de la neurociencia para la formación docente [The contribution of neuroscience to teacher training]. Actualidades Investigativas en Educación, 5(1).

Gayá, V. (2017). Método Waldorf: respeto al niño y su creatividad [Waldorf Method: respect for the child and his creativity]. El Siglo de Europa, 1213.

George, D., \& Mallery, P. (2003). SPSS for Windows step by step: A simple guide and reference. 11.0 update. Boston: Allyn \& Bacon.

Goetz, T., Nett, U. E., Martiny, S. E., Hall, N. C., Pekrun, R., Dettmers, S., \& Trautwein, U. (2012). Students' emotions during homework: Structures, self-concept antecedents, and achievement outcomes. Learning and Individual Differences, 22(2), 225-234.

González, D., \& Suerio, E. (2017). Uso del color en la infancia [Use of color in childhood]. Revista de estudios e investigación en psicología y educación, 4, 86-88. https://doi.org/10.17979/reipe.2017.0.04.2596

Gutman, S. A., \& Schindler, V. P. (2007). The neurological basis of occupation. Occupational therapy international, 14(2), 71-85. https://doi.org/10.1002/oti.225

González, P., Lacasa, P., \& Albuquerque, M. (2014). Los deberes escolares ¿Qué hay y qué buscamos? [Homework What is there and what are we looking for?] Cultura y Educación, 11(1), 21-36. https://www.tandfonline.com/doi/abs/10.1174/113564002320584817

Hargreaves, D. J. (1989). Children and the arts. London: Open University Press.

Hasio, C. (2011). Searching the soul: Veterans and their arts and crafts. Art Education, 64(6), 48-54.

Hattie, J., \& Clinton, J. (2001). The assessment of teachers. Teaching education, 12(3), 279-300.

Henward, A. S. (2018). Examining discursive formations in early childhood media research: A genealogical analysis. Global Studies of Childhood, 8(3), https://doi.org/10.1177/2043610618797512

Igelmo-Zaldívar J., \& Quiroga-Uceda, P. (2018). La pedagogía ligera en tiempos hipermodernos: el homeschooling, las escuelas Waldorf y la nueva pedagogía ignaciana [Light pedagogy in hypermodern times: the homeschooling, the Waldorf schools, and the new ignatian pedagogy]. Teoría de la Educación. Revista Interuniversitaria, 30(1), 75-94. http://dx.doi.org/10.14201/teoredu3017594

International Forum for Steiner/ Waldorf Education: Hague Circle. (2016) Key Characteristics of Waldorf Education. international.org/fileadmin/downloads/1605_Characteristics_IF_Arles.pdf

Izquierdo, G. A. (2016). Estructura de la emoción positiva de flow y la motivación autodeterminada y su relación en el rendimiento escolar en niños de 8 a 12 años [Structure of positive emotion flow and self-determined motivation and its relationship to school performance in 8-12 year olds]. Tesis doctoral. Zaragoza: Universidad de Zaragoza.

Jiménez, C. A. (2006). El sentido de los valores en las nuevas pedagogías [The meaning of values in the new pedagogies]. Colombia: Lúdica Colombia.

Jisu, H., Delorme, D. E., \& Reid, L. N. (2006). Perceived Third-Person effects and consumer attitudes on prevetting and banning DTC advertising. Journal of Consumer Affairs, 40(1), 90-116.

Kandel, E. (2000). Principles of Neural science. New York: McGraw Hill. 
Kelly, C. G., Cudney, S., \& Weinert, C. (2012). Use of creative arts as a complimentary therapy by rural women coping with a chronic illness. Journal of Holistic Nursing, 30(1), 48-54. http://dx.doi.org/10.1177/0898010111423418

Kwok, S.Y.C.L., \& Fang, S. A. (2020). Cross-Lagged Panel Study Examining the Reciprocal Relationships Between Positive Emotions, Meaning, Strengths use and Study Engagement in Primary School Students. Journal of Happiness Studies. https://doi.org/10.1007/s10902-020-00262-4

Malagón, G. A. (2017). Las escuelas Waldorf: La Comunidad Educativa Activa, clave para una Educación Integral [Waldorf Schools: The Active Educational Community, key to an Integral Education]. Forum Aragón: revista digital de FEAE-Aragón sobre organización y gestión educativa, 22, 32-34.

Malloch, S., \& Trevarthen, C. (2018). The human nature of music. Frontiers in Psychology, 9. https://doi.org/10.3389/fpsyg.2018.01680

Manzano, M. J., \& Álvarez-Monteserín. (2012). Liberarse de la tiranía de los libros de texto [Free yourself from the tyranny of textbooks]. Cuadernos de Pedagogía, 428.

Montanero, M. (2019). Métodos pedagógicos emergentes para un nuevo siglo ¿qué hay realmente de innovación? [Emerging pedagogical methods for a new century: what is really innovative?] Teoría de la educación. Revista Interuniversitaria, 31(1), 5-34, 2019. https://doi.org/10.14201/teri.19758

Moreno, M. (2010). Pedagogía Waldorf [Waldorf Pedagogy]. Arteterapia: Papeles de arteterapia y educación artística, 5, 203-209.

Mosterín, J. (2008). Lo mejor posible: Racionalidad y acción humana [The best possible: Rationality and human action]. Madrid: Alianza.

Lyubomirsky, S., \& Lepper, H. S. (1999). A measure of subjective happiness: Preliminary reliability and construct validation. Social Indicators Research, 46, 137-155.

Penalva, J. (2008). Claves del modelo educativo en España: sobre el modelo de enseñanza y de profesor [Keys to the educational model in Spain: on the teaching and teaching model]. Madrid: La Muralla.

Peterson, C., \& Bossio, L.M. (1991). Health and optimism. New York: Oxford, University Press.

Prager, D. R. (2004). Learning through Creating an Urban Waldorf Elementary School Background. Online Yearbook of Urban Learning, Teaching, and Research, 1, 19-26.

Oberski, I. (2011). Rudolf steiner's philosophy of freedom as a basis for spiritual education? International Journal of Children's Spirituality, 16(1), 5-17. http://dx.doi.org/10.1080/1364436X.2010.540751

Oberski, I., \& Mcnally, J. (2007). Holism in teacher development: A goethean perspective. Teaching and Teacher Education, 23(6), 935-943. http://dx.doi.org/10.1016/j.tate.2006.07.009

Quiroga, U. P., \& Girard, O. (2015). La expansión internacional de la pedagogía Waldorf: un análisis histórico [The international expansion of Waldorf education: an historical analysis]. Temps d'Educació, 48, 91-109.

Resende, T. F., Nogueira, C. M., \& Nogueira, M. A. (2011). Escolha do estabelecimento de ensino e perfis familiares: Uma faceta a mais das desigualdades escolares [Choice of school and family profiles: A facet of more school inequalities]. Educacao e Sociedade, 32(117), 953-970.

Reynolds, F. (2012). Art therapy after stroke: Evidence and a need for further research. The Arts in Psychotherapy, 39(4), 239-244. http://dx.doi.org/10.1016/j.aip.2012.03.006

Ried, A. (2015). La experiencia de ocio al aire libre en contacto con la naturaleza, como vivencia restauradora de la relación ser humano-naturaleza [The experience of leisure outdoors in contact with nature, as an experience that restores the relationship between human beings and nature]. Revista Latinoamericana, 14 (41), 499-516.

Schueller, S. M., \& Seligman, M. E. (2010). Pursuit of pleasure, engagement, and meaning: Relationships to subjective and objective measures of well-being. The Journal of Positive Psychology, 5(4), 253-263.

Seligman, M. E., Ernst, R. M., Gillham, J., Reivich, K., \& Linkins, M. (2009). Positive education: Positive psychology and classroom interventions. Oxford review of education, 35(3), 293-311.

Sliwka, A. (2008). The contribution of alternative education, In: OECD, Innovating to learn - learning to innovate (pp. 93-112). Paris: OECD/CERI. http://dx.doi.org/10.1787/9789264047983-6-en

Smidt, S. (2013). The developing child in the 21st century: A global perspective on child development. London; Routledge. http://dx.doi.org/10.4324/9780203483640

Soy, S. (1997). The case study as a research method uses \& users of information- LIS391.D1-Spring. pp. 2. Retrived from https://www.ischool.utexas.edu/ ssoy/usesusers/l391d1b.htm on 5 July 2015.

Sociedad Española de Pedagogía (ed.) (2003). El juego es un derecho y una necesidad de la infancia [Play is a child's right and need]. Bordón. Revista de Pedagogía, 65, 103-117.

Strauss, A., \& Corbin, J. (2008). Basics of Qualitative Research: Techniques and Procedures for Developing Grounded Theory. Thousand Oaks, California: Sage Publications. 
Sullivan, P. (2000). Playfulness as mediation in communicative language teaching in a Vietnamese classroom. In J.P. Lantolf (Ed.), Sociocultural theory and second language learning (pp. 115-131). Oxford University Press.

Taylor, A., \& Kuo, F. (2006). Is contact with nature important for healthy child development? State of the evidence. In C. Spencer \& M. Blades (Eds.), Children and their Environments: Learning, Using and Designing Spaces (pp. 124-140). Cambridge: Cambridge University Press. http://dx.doi.org/10.1017/CB09780511521232.009

Taylor, S. J., Bogdan, R., \& DeVault, M. (2015). Introduction to qualitative research methods: A guidebook and resource. Hoboken, Nueva Jersey: John Wiley \& Sons.

Trautwein, U. (2007). The homework-achievement relation reconsidered: Differentiating homework time, homework frequency, and homework effort. Learning and Instruction, 17(3), 372-388.

Valle, A., Pan, I., Nuñez, J. C., Rosário, P., Rodríguez, S., \& Regueiro, B. (2015) Homework and academic achievement in Primary Education. Anales de psicología, 31(2), 562-569. http://dx.doi.org/10.6018/analesps.31.2.171131

Velasco, J. J. (2003). La investigación etnográfica y el maestro [Ethnographic research and the teacher]. Tiempo de Educar, 4(7), 153-169.

Verma, S., Sharma, D., \& Larson, R. W. (2002). School stress in India: Effects on time and daily emotions. International Journal of Behavioral Development, 26(6), 500-508.

Wells, N. M. (2000). At home with nature: Effects of 'greenness' on children's cognitive functioning. Environment and Behavior, 32(6), 775-795. http://dx.doi.org/10.1177/00139160021972793

Zaidel, D. W. (2015). Neuropsychology of art: Neurological, cognitive, and evolutionary perspective. East Sussex, United Kingdom: Psychology Press.

Zaidel, D. W. (2018). Culture and art: Importance of art practice, not aesthetics, to early human culture. In J. F. Christensen \& A. Gomila (eds.), The Arts and The Brain: Psychology and Physiology Beyond Pleasure (pp. 25-40). Netherlands: Eselvier. http://dx.doi.org/10.1016/bs.pbr.2018.03.001

Zimmerman, B. J., \& Kitsantas, A. (2005). Students' perceived responsibility and completion of homework: The role of self-regulatory beliefs and processes. Contemporary Educational Psychology, 3, 397417.

Yin, R. K. (2017). Case study research and applications: Design and methods. Thousand Oaks, California: Sage Publications. 